*УДК 657

Талах Т.А. к.е.н., доцент

Бондарук Х.В., асистент

Луцький національний технічний університет

\title{
ОРГАНІЗАЦІЙНІ АСПЕКТИ АНАЛІЗУ І КОНТРОЛЮ ЗА РІВНЕМ ЕКОНОМІЧНОЇ БЕЗПЕКИ НА ПІДПРИЕМСТВІ
}

У статті розглянуто теоретичні положення та розроблено методикоприкладні рекомендації щодо організації економічного аналізу економічної безпеки підприємства та системи контролю за її рівнем.

Ключові слова: економічна безпека, зовнішній аналіз, внутрішній аналіз, організація аналізу економічної безпеки підприємства.

\section{Talakh T., Bondaruk H. \\ ORGANIZATIONAL ASPECTS OF ANALYSIS AND CONTROL OF ECONOMIC SECURITY AT ENTERPRISE}

Theoretical provisions are considered in the article and methodological and applied recommendations on organization of economic analysis of economic security of the enterprise and system of control over its level are developed.

The lack of a unified and complete opinion on the economic security of the enterprise necessitates the need to continue finding ways and ways to solve this problem. Considering the main priorities and eliminating the shortcomings and contradictions, in our opinion the economic security of the enterprise is a condition characterized by stability and balance, protection from the negative impact of the internal and external environment, neutralization of threats to the efficiency of use of available resources, elimination of obstacles in the implementation of life - important interests and ensuring sustainable development.

Continuous monitoring and assessment of the economic security of the enterprise should be the result of the interaction of all interested services of the enterprise. This requires appropriate methodological, organizational, information and technical support.

Enterprises can be established department (department, service, department) of economic security, whose activities are managed by its manager. On the other hand, there may be the creation of a working group of specialists. The organizational forms of economic security of an enterprise are determined by the composition of the apparatus and the technical level of security management. Improving the methods of analytical and power work to ensure the economic security of the enterprise requires the development of analytical functions of all services of enterprises.

* Талах Т.А., Бондарук Х.В. 
Economic security issues are the responsibility of not only the employees of economic services, but also the technical departments (chief mechanic, energy, technologist, etc.). Economic services of the enterprise plan economic activity, carry out supply and sale of products, organize labor, financial work, accounting and control of economic activity.

Internal analysis of economic security of enterprises is carried out by employees of enterprises, and external - marketing and economic intelligence services of the enterprise. The analytical department (accounting department) should carry out both external and internal analysis of its economic security in the complex.

Key words: economic security, external analysis, internal analysis, organization of economic security analysis of the enterprise.

Талах Т.А., Бондарук Х.В.

\section{ОРГАНИЗАЦИОННЫЕ АСПЕКТЫ АНАЛИЗА И КОНТРОЛЯ ЗА УРОВНЕМ ЭКОНОМИЧЕСКОЙ БЕЗОПАСНОСТИ НА ПРЕДПРИЯТИИ}

В статье рассмотрены теоретические положения и разработаны методикоприкладные рекомендации по организации экономического анализа экономической безопасности предприятия и системы контроля за ее уровнем.

Ключевые слова: экономическая безопасность, внешний анализ, внутренний анализ, организация анализа экономической безопасности предприятия.

Постановка проблеми у загальному вигляді та ії зв'язок 3 важливими науковими та практичними завданнями Підвищення ефективності діяльності промислових підприємств та їх адаптація до нових економічних умов забезпечується розвитком методичних можливостей економічного аналізу на основі комплексної реалізації його функцій у господарських процесах.

У сучасній економічній ситуації виробничі одиниці мають повну економічну самостійність щодо ведення економічної політики, формування портфеля замовлень, організації виробництва i збуту продукції, отримання прибутку. Зростання економічного потенціалу будь-якого підприємства залежить і від наявності системи забезпечення економічної безпеки. Це свідчить про те, що зростає необхідність вивчення, діагностики та розвитку аналітичних інструментів зміцнення економічної безпеки підприємства.

Аналіз останніх досліджень, у яких започатковано вирішення проблеми. Дослідження теоретичних основ економічної безпеки підприємства, а також коло інших питань, пов'язаних 3 цією проблемою, знайшли своє відображення в наукових працях 
багатьох вітчизняних та зарубіжних науковців (Н. Вавдіюк, М. Васильців Т. Г. Дацків Р. М., Козаченко Г.В., Отенко І. П., Картузов Є., Коваленко О.В. Худолій Л. М.).

Аналіз літературних джерел свідчить про відсутність єдності в поглядах вчених до визначення сутності економічної безпеки підприємства, методики іiі оцінки та організаційних аспектів що обумовлює подальше вивчення даної теми.

Цілі статті. Метою написання статті є обгрунтування теоретичних положення та розробка методико-прикладних рекомендацій щодо організації економічного аналізу економічної безпеки підприємства та системи контролю за ії рівнем.

Виклад основного матеріалу дослідження 3 повним обгрунтуванням отриманих наукових результатів Наукові дослідження показують, що неможливо знайти вихід із кризи, стабілізувати економічну ситуацію, створити ефективний механізм ведення бізнесу без єдиної системи економічної безпеки. Відзначимо, що рівень економічної безпеки бізнесу залежить від того, наскільки добре його керівництво може уникнути реальних загроз та усунути шкідливі наслідки деяких негативних компонентів зовнішнього та внутрішнього середовища.

Економічна безпека підприємства характеризується ії̈ економічним станом, що забезпечує стійкість його діяльності та розвитку, його фінансовий та комерційний успіх. Проблеми забезпечення безпеки, які останнім часом є важливим питанням, представлені в світовій науковій літературі з точки зору охоплення ризиків, загроз, небезпек та їх наслідків. На практиці існують певні шляхи розвитку економічної безпеки підприємства, і в більшості випадків вони стратегічно спрямовані, супроводжуються процесами якісних організаційних, інноваційних та інвестиційних змін та створюють умови для стабільної та ефективної діяльності підприємства.

Найважливішими факторами, що впливають на економічну безпеку підприємства, є ступінь досконалості законодавчої бази, рівень оподаткування, доступ на світові ринки збуту, інвестиційна привабливість регіону, держави. Насамперед, економічна безпека підприємства залежить від економічної безпеки держави, регіону, адже грунтується на їхньому фінансовому, сировинному та виробничому потенціалі, перспективах розвитку.

Кожен із науковців поняття економічної безпеки трактує по різному. Одні науковці його розуміють як стан, за якого досягаєть- 
ся стійкий економічний та фінансовий розвиток; інші, як заходи щоб досягнути такий стан. Більш коректним виглядає перше визначення економічної безпеки підприємства Таке визначення може вважатися достатньо коректним, через те що заходи та методи по досягненню такого стану - це управління економічною безпекою.

Відсутність єдиної та повної думки про економічну безпеку підприємства обумовлює необхідність подальшого пошуку шляхів та способів вирішення цієї проблеми. Розглянемо сучасні та найбільш актуальні думки вчених щодо визначення поняття «економічна безпека підприємства».

Коваленко О.В., Лисенко Л.В. розглядають економічної безпеки підприємства «як гармонізацію в часі та просторі економічних інтересів підприємства 3 інтересами пов'язаних 3 ним суб'єктів зовнішнього середовища, що діють поза межами підприємства» [5]. Але вченими не розглядається спроможність управлінської системи підприємства ефективно управляти ресурсами 3 метою забезпечення певного резерву стійкості для адекватної реакції на зміни у внутрішньому та зовнішньому середовищі.

3 точки зору Ілляшенко С. економічна безпека - це стан ефективного використання ресурсів та усіх існуючих зовнішніх та внутрішніх можливостей, що дозволить запобігти ринковим загрозам $\mathrm{i}$ забезпечує виживання та сталий розвиток на ринку. Вчений трактує економічну безпеку як стан, за якого ефективно використовуються матеріальні, фінансові, трудові ресурси підприємства, враховуються зовнішні та внутрішні можливості його розвитку. Це дозволять сформувати систему попередження усіх видів загроз.

Васильців Т. Г. розуміє, що економічна безпека підприємства - комплекс заходів, які сприяють підвищуванню фінансової стійкості господарчих суб'єктів в умовах ринкової економіки, що захищають їх комерційні інтереси від впливу негативних ринкових факторів [2].

Покропивний С. Ф. трактує: «економічна безпека підприємства» як такий стан підприємницьких можливостей та корпоративних ресурсів, при якому забезпечується найефективніше їх використання для збереження сталого функціонування та ефективного науково-технічного й соціального розвитку, при цьому запобігання внутрішнім та зовнішнім загрозам.

Хоменко О.А розглядають економічну безпеку підприємства як підсистему національної економічної безпеки та визначають іï 
як економічний стан підприємства, незмінний по відношенню до внутрішніх і зовнішніх змін фінансово-господарської діяльності [8]. Таке визначення розглядає економічну безпеку в статиці і не враховує необхідність відповідної реакції на зміни, що відбуваються.

Доцільно відзначити, що для окремих підходів характерне доволі вузьке трактування економічної безпеки підприємства і зосередження уваги виключно на одному аспекті, наприклад - захист від внутрішніх і зовнішніх загроз; присутнє і необдумано широке трактування, коли перед економічної безпеки ставляться завдання, які повинні виконувати інші органи управління, наприклад - контроль за ефективністю використання ресурсів тощо. Виявлені суперечності та недоліки у визначенні економічної безпеки підприємства на поточному етапі розвитку наукової думки спонукали до формування власного трактування, яке б в подальшому можна було конкретизувати щодо певної окремою функціональної сфери.

Беручи за основу виділені пріоритети та усуваючи визначені вище недоліки й суперечності, на нашу думку економічна безпека підприємства - це стан для якого є характерним стійкість і рівновага, захищеність від негативного впливу внутрішнього і зовнішнього середовища, нейтралізація загроз щодо ефективності використання наявних ресурсів, усунення перешкод у реалізації життєвоважливих інтересів та забезпеченні сталого розвитку.

Під економічною безпекою підприємства, на нашу думку, слід розуміти як комплексну характеристику результатів діяльності підприємства, яка зумовлена узгодженням цілей та передбачає раціональне використання ресурсів.

3 урахуванням завдань, умов конкурентної боротьби, специфіки бізнесу, технологічних особливостей, конкурентної стратегії, стадії життєвого циклу підприємства вибудовується його система економічної безпеки. Лише незначна частка підприємств виділяє такий підрозділ як система економічної безпеки, частіше за все цими питаннями займаються менеджери, аналітики, охорона підприємства.

На вітчизняних підприємствах, більшого розвитку отримала силова безпека, але автори наголошують на тому, що силова безпека підприємства є лише окремою складовою його економічної безпеки. Для всіх рівнів забезпечення економічної безпеки кожне підприємство здійснює структурування та комбінування елементів 
системи економічної безпеки індивідуально. При чому не на всіх підприємствах є всі виділені елементи системи економічної безпеки.

Нині порушується питання про створення системи спостереження за рівнем економічної безпеки підприємства $з$ метою превентивних дій і вживання необхідних заходів захисту й протидії.

Постійне спостереження і оцінка економічної безпеки підприємства повинно бути результатом взаємодії всіх зацікавлених служб підприємства. Для цього необхідне відповідне методичне, організаційне, інформаційне та технічне забезпечення.

На підприємствах може бути створено управління (департамент, служба, відділ) економічної безпеки, діяльністю якої управляє іiі керівник, який, в свою чергу, підпорядковується директору підприємства. Це особлива умова, щоб не було проміжних ланок управління та не порушувалась при передачі цими ланками конфіденційність інформації.

Іншим сценарієм організації роботи щодо забезпечення економічної безпеки на підприємстві може бути створення робочої групи спеціалістів, які крім своїх основних функцій займаються забезпеченням економічної безпеки підприємства. Такий організаційний сценарій може бути регламентований внутрішніми документами.

У нормативних документах, які визначають організацію діяльності служби безпеки підприємств, виокремлюються конкретні об'єкти, що підлягають захисту від потенційних загроз і протиправних посягань.

Організаційні форми економічної безпеки підприємства визначаються складом апарату і технічним рівнем управління безпекою. Удосконалення методів аналітичної та силової роботи щодо забезпечення економічної безпеки підприємства вимагає розвитку аналітичних функцій всіх служб підприємств.

Питання економічної безпеки входять в обов'язок не тільки працівників економічних служб, а й технічних відділів (головного механіка, енергетика, технолога та ін.). Економічні служби підприємства планують господарську діяльність, здійснюють постачання і реалізацію продукції, організовують працю, фінансову роботу, облік і контроль господарської діяльності.

Внутрішній аналіз економічної безпеки підприємств здійснюється працівниками підприємств, а зовнішній - маркетинговими 
службами та службами економічної розвідки підприємства. Аналітичний відділ (бухгалтерія) повинні здійснювати як зовнішній, так і внутрішній аналіз його економічної безпеки в комплексі.

Розподіл обов'язків 3 питань економічної безпеки підприємств хімічної галузі представлено в табл. 1 .

Таблиця 1

Організація економічного аналізу рівня економічної безпеки підприємства

\begin{tabular}{|c|c|}
\hline $\begin{array}{l}\text { Відділ підп- } \\
\text { риємства }\end{array}$ & $\begin{array}{c}\text { Напрями аналітичних досліджень } \\
\text { з питань економічної безпеки }\end{array}$ \\
\hline 1 & 2 \\
\hline $\begin{array}{l}\text { Планово- } \\
\text { економіч- } \\
\text { ний відділ } \\
\text { (відділ еко- } \\
\text { номічного } \\
\text { аналізу, } \\
\text { аналітичний } \\
\text { відділ }\end{array}$ & $\begin{array}{l}\text { - складання плану аналітичної роботи щодо економіч- } \\
\text { ної безпеки і контроль за його виконанням; } \\
\text { - методичне забезпечення внутрішнього та зовнішньо- } \\
\text { го аналізу економічної безпеки; } \\
\text { - організація й узагальненням результатів комплексно- } \\
\text { го аналізу безпеки підприємства і його підрозділів; } \\
\text { - дослідження можливостей потенційного забезпечення } \\
\text { економічної безпеки в майбутньому; } \\
\text { - розробка заходів щодо ефективної витрати ресурсів на } \\
\text { поточне та потенційне забезпечення економічної безпе- } \\
\text { ки. }\end{array}$ \\
\hline $\begin{array}{c}\text { Виробничий } \\
\text { відділ }\end{array}$ & $\begin{array}{l}\text { інтеграція аналізу виробництва та маркетинговий аналіз } \\
\text { для дослідження доцільності випуску продукції в про- } \\
\text { гнозованих розмірах та не допустити затоварювання } \\
\text { готовою продукцією. }\end{array}$ \\
\hline $\begin{array}{c}\text { Технічні } \\
\text { відділи } \\
\text { головного } \\
\text { механіка й } \\
\text { енергетика }\end{array}$ & $\begin{array}{l}\text { - аналіз безпечності стану експлуатації машин і устат- } \\
\text { кування, виконання планів-графіків ремонту і модерні- } \\
\text { зації устаткування, якості і собівартість ремонтів, пов- } \\
\text { ноту використання устаткування і виробничих потуж- } \\
\text { ностей, раціональність споживання енергоресурсів. } \\
\text { - надання конкретних рекомендацій щодо впроваджен- } \\
\text { ня енергозберігаючих технологій та нових більш ощад- } \\
\text { них технологічних процесів. }\end{array}$ \\
\hline $\begin{array}{c}\text { Відділ тех- } \\
\text { нічного } \\
\text { контролю }\end{array}$ & $\begin{array}{l}\text { - аналіз екологічну, токсичну або продовольчої безпеч- } \\
\text { ності сировини і готової продукції, брак і пов’язані з ним } \\
\text { утрати, рекламації покупців. } \\
\text { Відділ забезпечить підвищення рівня економічної без- } \\
\text { пеки підприємства у випадку розробки комплексу захо- } \\
\text { дів щодо зменшення браку, підвищення якості продук- } \\
\text { ції, дотримання технологічної дисципліни. }\end{array}$ \\
\hline
\end{tabular}


"Економічні науки". - Серія "Облік і фінанси". - Випуск 16 (61). - 2019.

Продовження табл. 1

\begin{tabular}{|c|c|}
\hline 1 & 2 \\
\hline $\begin{array}{c}\text { Відділ пос- } \\
\text { тачання }\end{array}$ & $\begin{array}{l}\text { - контроль своєчасності і якості матеріально-технічного } \\
\text { забезпечення виробництва, виконання плану постачань } \\
\text { за обсягом, номенклатурою, термінами, якістю, станом і } \\
\text { збереженістю складських запасів, дотримання норм від- } \\
\text { пустки матеріалів, транспортно-заготівельні витрати, } \\
\text { фактичну вартість матеріальних ресурсів, що здобува- } \\
\text { ються. }\end{array}$ \\
\hline Відділ збуту & $\begin{array}{l}\text { - аналіз виконання договірних зобов’язань і планів } \\
\text { постачань продукції споживачам за обсягом, якістю, } \\
\text { термінами, номенклатурою; } \\
\text { - аналіз виконання плану реалізації продукції і витрат } \\
\text { на неї; } \\
\text { - контроль дотримання норм складських запасів і збе- } \\
\text { реженість готової продукції; } \\
\text { - вивчення ринку збуту і раціональності господарських } \\
\text { зв'язків. При цьому економічна безпека підприємства } \\
\text { прямо пропорційно залежить від своєчасності розрахун- } \\
\text { ків за відвантажену продукції. Несвоєчасність розраху- } \\
\text { нків призводить до підвищення ризиків утрати частини } \\
\text { реальної вартості продукції через інтенсифікацію ін- } \\
\text { фляційних процесів. }\end{array}$ \\
\hline $\begin{array}{c}\text { Відділ праці } \\
\text { і заробітної } \\
\text { плати }\end{array}$ & $\begin{array}{l}\text { - аналіз рівня організації праці, чисельності персоналу } \\
\text { за всіма категоріями і професіями підприємства і його } \\
\text { структурних підрозділів, рівень використання робочого } \\
\text { часу, витрати фонду заробітної плати; } \\
\text { - аналіз ефективності форм і систем оплати і стимулю- } \\
\text { вання праці, рівень продуктивності праці. } \\
\text { Від рівня матеріального та морального стимулювання } \\
\text { працівників залежить рівень економічної безпеки підп- } \\
\text { риємства. При зниженні такого рівня працівник може } \\
\text { продати конфіденційну інформацію конкурентам, розк- } \\
\text { рити комерційну таємницю, працівник не зацікавлений } \\
\text { в підвищенні обсягів реалізації продукції. }\end{array}$ \\
\hline $\begin{array}{l}\text { Бухгалтерія } \\
\text { та фінансо- } \\
\text { вий відділ }\end{array}$ & $\begin{array}{l}\text { - аналіз виконання кошторисів загальновиробничих, } \\
\text { адміністративних витрат та витрат на збут, кошторису } \\
\text { витрат на виробництво, собівартість реалізованої про- } \\
\text { дукції, виконання плану прибутку і його використання; } \\
\text { - аналіз бухгалтерського балансу, фінансового стану, } \\
\text { витрати оборотних коштів і спеціальних фондів; } \\
\text { - контроль фінансового стану і платоспроможності } \\
\text { підприємства }\end{array}$ \\
\hline
\end{tabular}


Особливу увагу приділяють контролю дотримання економічної безпеки підприємства. В системі фінансово-економічної безпеки виділяють три ключові складові діяльності підсистеми контролю та оцінки:

1. Методологічна складова - розробка методології оцінки рівня економічної безпеки, участь у розробці антикризової програми.

2. Безпосередньо контроль - забезпечення достовірності даних від інших підсистем, контроль за виконанням підсистемами поставлених перед ними завдань.

3. Аналітична частина - обмін інформаційними потоками, аналіз змісту інформаційних потоків, аналіз відхилень, виявлення причин кризових ситуацій, надання рекомендацій керівнику.

Комплекс контролю для забезпечення економічної безпеки підприємства охоплює елементи, представлені в табл. 2.

Таблиця 2

Складові контролю для забезпечення економічної безпеки підприємства

\begin{tabular}{|c|c|}
\hline $\begin{array}{l}\text { Елементи } \\
\text { контролю }\end{array}$ & Зміст заходів \\
\hline $\begin{array}{c}\text { 1.Підсистема } \\
\text { контролю та оці- } \\
\text { нки результатів }\end{array}$ & $\begin{array}{l}\text { - контроль за виконанням підсистемою своїх фун- } \\
\text { кцій; } \\
\text { - оцінка результативності заходів з нейтралізації } \\
\text { кризи; } \\
\text {-забезпечення обміну інформаційними потоками }\end{array}$ \\
\hline $\begin{array}{c}\text { 2. Об’єкти дії } \\
\text { підсистеми } \\
\text { контролю }\end{array}$ & $\begin{array}{l}\text { 2.1. Діяльність } \\
\text { - антикризові заходи; } \\
\text { - поточна діяльність суб’єкта підприємництва. } \\
\text { 2.2.Результати: } \\
\text { - висновки підсистеми діагностики; } \\
\text { - результати антикризових заходів; } \\
\text { - результати діяльності суб’єкта підприємництва } \\
\text { за певний період }\end{array}$ \\
\hline
\end{tabular}

Висновки. Таким чином, економічна безпека підприємства це стан для якого є характерним стійкість і рівновага, захищеність від негативного впливу внутрішнього і зовнішнього середовища, нейтралізація загроз щодо ефективності використання наявних ресурсів, усунення перешкод у реалізації життєво-важливих інтересів та забезпеченні сталого розвитку підприємства. Постійне спо- 
стереження, оцінка, контроль за рівним економічної безпеки та розподіл обов'язків за цими діями є одним із основним завдань сучасного підприємства.

1. Вавдіюк Н.С., Герасимчук 3.В. Економічна безпека регіону діагностика та механізм забезпечення: монографія Луцьк 2006. 243 с.

2. Васильців Т. Г. Економічна безпека підприємництва України: стратегія та механізми зміцнення: монографія Львів: Арал, 2008. 384 с.

3. Дацків Р. М. Економічна безпека у глобальному вимірі. Актуальні проблеми економіки. 2014. № 7 (37). С. 143-153.

4. Картузов Є. П. Вплив ризиків і загроз на стан фінансової безпеки підприємств. Економіка та управління підприємствами. 2012. № 9 (135). С. 115-124

5. Коваленко О.В., Лисенко Л.В. Підходи до визначення поняття економічної безпеки підприємства. Глобальні та національні проблеми економіки, 2014. № 6. C. 48-57.

6. Меліхова Т. О. Механізм управління економічною безпекою підприємства: підходи до визначення. Агросвіт № 3,2018

7. Отенко І. П., Іващенко Г. А., Воронков Д. К. Економічна безпека підприємства: навч. посіб. Харків. Вид. ХНЕУ, 2012. 313 с.

8. Хоменко О.А Аналіз ідентифікації ознак механізму управління фінансовою безпекою молокопереробних підприємств Економічний дискурс Міжнародний науковий журнал Випуск 1. 2019

9. Худолій Л. М. складові економічної безпеки суб'єктів господарської діяльності. Ефективна економіка. 2017. № 1. С. 36 - 45.

*УДК 657.37:330

Шевчук К.В., к.е.н., доцент

Бондар B.I.

Національний університет біоресурсів і природокористування України

\section{ФІНАНСОВІ РЕЗУЛЬТАТИ ЯК ЕКОНОМІЧНА КАТЕГОРІЯ ТА ОСОБЛИВОСТІ ВІДОБРАЖЕННЯ ЇХ В ОБЛІКУ ТА ЗВІТНОСТІ ПІДПРИЄМСТВА}

У статті розглянуто сутність фінансових результатів діяльності підприємства, визначено ї місце у системі бухгалтерського обліку та звітності суб'єктів господарювання. Виділено та узагальнено проблеми інформаційного забезпечення процесу управління фінансовими результатами.

* Шевчук К.В., Бондар В.I. 